\title{
A Construção do sentido e a retórica das empresas na web
}

\section{Strategic messages of companies in the web}

\author{
Jacquelaine Florindo Borges ${ }^{7}$ \\ Valdir Machado Valadão Júnior ${ }^{2}$
}

\begin{abstract}
Resumo
Este artigo analisa como as empresas brasileiras fazem uso intencional da linguagem em seus websites para influenciar percepções, crenças, sentimentos e ações de públicos-alvo e como este discurso absorve elementos do contexto social. A análise das afirmações autodescritivas de 40 empresas pesquisadas é conduzida a partir de uma perspectiva históricocritica que considera o discurso uma prática social. Para a coleta e análise dos dados, foram utilizados a análise retórica e alguns pressupostos da análise crítica do discurso, tendo a Internet como meio de pesquisa. Os resultados indicam como a cultura e o poder estão presentes na linguagem das empresas na Web. Revelam, também, o ambiente virtual como um novo espaço para a construção do sentido, no qual as empresas ampliam suas fronteiras simbólicas e constroem retoricamente sua legitimação.
\end{abstract}

Palavras-chave: cultura; discurso; legitimação; poder; retórica.

\section{Abstract}

The objective of this paper is to analyze how Brazilian companies make intentional use of language in their websites to influence the target public's perceptions, beliefs, feelings and actions, and how this discourse absorbs elements of social context. The self-descriptive statement analysis of the forty companies is conducted from a historical and critical perspective which considers discourse as a social practice. Rhetorical analysis and Critical Discourse Analysis presumptions - being the Internet a means of research - were used for gathering and analyzing the data. Results indicate how culture and power are present in the language of web companies. They also reveal that the virtual space is a new place for the construction of meaning, a place in which companies enlarge their symbolic borders and rhetorically build their legitimacy.

Keywords: culture; discourse; legitimacy; power; rhetoric.

\section{Introdução}

Doriana derrete na boca do brasileiro pela primeira vez, enquanto a Becel faz ponte entre sabor e saúde. A Gelato vai de Cornetto para seduzir o paladar, ao passo que a Kibon começa a refrescar o calor nordestino. No fim de tudo, Close Up arranca sorrisos de gel e as mulheres desfilam a maciez de Vasenol.

Site da Unilever, "História", década de 70.

Desde o final do século XX, novas tecnologias de comunicação passaram a fazer parte, de forma mais intensa, da vida das pessoas e do cotidiano das instituições. A outdoors, rádio, televisão, revistas e jornais junta-se a Internet, um meio de comunicação global. A emergência de "um mundo mediado" provoca um excesso de

\footnotetext{
1 Mestre em Administração pela Universidade Federal de Uberlândia/UFU. Professora da FAGEN/UFU e da Faculdade Politécnica de Uberlândia. Endereço: Av. Mato Grosso, 1982 - Uberlândia/ Minas Gerais, CEP 38400-724 - Brasil. E-mail: jac.borges@uol.com.br

${ }^{2}$ Doutor em Engenharia da Produção pela UFSC e Mestre em Administração pela UFPR.. Professor da FAGEN / Universidade Federal de Uberlândia. Endereço: Av. João Naves de Ávila, 2121, Bloco F, Campus Santa Mônica, Uberlândia/Minas Gerais, CEP: 38400-9025 - Brasil. E-mail: valdirjr@ufu.br

Artigo submetido em junho de 2006 e aceito em março de 2007
} 
mensagens e clamores a serem ouvidos, excesso de informação e variados meios de persuasão. A Internet oferece novas maneiras de administrar a informação e de comunicá-la, novas maneiras de articular desejos e de influenciar e agradar, novas maneiras de criar, transmitir e manter significado (CASTELLS, 2003; GALLI, 2004; LÉVY, 1999; SILVERSTONE, 2002; THOMPSON, 2002).

A Web constitui um novo espaço para as práticas humanas de comunicação. Ali, as empresas articulam imagens, texto e som, tornando a comunicação mais envolvente, com possibilidades de ampliação do sentido. Em seus websites, as empresas se dirigem a uma audiência universal, o que não exclui públicos-alvo, por meio de um discurso híbrido de informação e publicidade. Todavia, é necessário considerar que a disseminação do uso da Internet ocorre em um ambiente no qual cresce o questionamento acerca da existência e do papel das empresas. Estas enfrentam pressões de diferentes grupos de interesse, como governos, ONGs (Organizações Não-Governamentais) e outras organizações da sociedade civil, OIGs (Organizações Intergovernamentais) e a própria concorrência capitalista, que demandam respostas.

Nesse contexto, a retórica das empresas em seus websites busca congruência com as demandas sociais mais amplas e, ao mesmo tempo, procura influenciar identidades sociais, relações sociais e sistemas de conhecimento e crença, de modo que a empresa possa obter a aprovação e o apoio para sua existência e seus objetivos. $\mathrm{O}$ uso intencional da linguagem não implica que as companhias sejam sempre bem-sucedidas. Elas podem ser mais ou menos efetivas e, até mesmo, gerar resultados contrários àqueles pretendidos.

Ainda que necessária para a compreensão do processo de gestão e da organização contemporânea, é incipiente a análise do uso que as empresas fazem da Web para difundir uma visão de mundo e buscar a legitimação organizacional. A presente pesquisa contribui nesse sentido, ao analisar como as 40 empresas - de 20 setores diferentes, indicadas "Melhores e Maiores" pelo Anuário "As 500 maiores empresas brasileiras", da revista Exame de julho de 2004 - fazem uso intencional da linguagem na Web. Ao agir retoricamente, as empresas visam a influenciar percepções, crenças, sentimentos e ações de públicos-alvo, ao mesmo tempo, o discurso organizacional é moldado por elementos do contexto econômico, cultural e político.

Conforme Reboul (2000, p. 139), a leitura retórica é um diálogo, que "critica e pondera, sem se abster de admirar, tendo como postulado que o texto, tanto em sua força quanto em suas fraquezas, pode ensinar alguma coisa". A análise crítica do discurso pode levar a uma compreensão de como a cultura e o poder estão presentes na linguagem das empresas na Web, e do modo como as organizações se apropriam de um novo espaço, o espaço virtual, para a construção do sentido e ampliação de suas fronteiras simbólicas.

Este artigo está estruturado do seguinte modo: inicialmente, são discutidos conceitos-chave e suas interrelações: cultura, poder e a construção de um discurso que busca a legitimação organizacional. Empreende-se, ainda, uma análise da situação retórica das empresas de modo que se compreenda "contra o quê?" e "por quê?" as empresas falam, respondem, argumentam. As seções seguintes tratam, respectivamente, dos procedimentos metodológicos e da análise retórica: identifica-se o tipo de discurso das companhias, os aspectos definidores do retor (aquele que age retoricamente) e como as empresas se auto-afirmam em seus websites. A análise das afirmações autodescritivas das empresas em seus websites e o papel da retórica na busca das empresas por legitimação, bem como as contribuições deste trabalho para uma compreensão da retórica organizacional, são apresentadas em seguida. As conclusões apontam a necessidade de ampliação do conhecimento sobre o uso que as empresas fazem da Web: como se autodefinem e como se apropriam deste espaço. 


\section{A Web como um novo espaço para a construção do sentido}

A Internet e as demais tecnologias são coisas sociais, impregnadas pelo simbólico, vulneráveis a paradoxos e contradições da vida social, tanto em sua criação quanto em seu uso. Segundo Silverstone (2002), a mídia não é uma força desencarnada operando contra nós, mas parte de uma realidade da qual participamos, que dividimos e sustentamos por meio de nossa fala e de nossas intervenções diárias. A tecnologia é imaginada, fabricada, reinterpretada durante seu uso pelos homens, como também é o próprio uso intensivo de ferramentas, juntamente com a linguagem e as instituições sociais complexas, que constituem a humanidade enquanto tal (CASTELLS, 2003; LÉVY, 1999).

As tecnologias da mídia como práticas e como objetos materiais, simbólicos e catalisadores da ação são eficazes apenas mediante os atos de indivíduos e instituições e, nesse sentido, constituem-se parte crucial do processo político e da luta por significado e controle (SILVERSTONE, 2002; THOMPSON, 2002). A linguagem é um meio pelo qual atores sociais mobilizam significado, que pode levar à manutenção, negociação ou reprodução das estruturas sociais assentadas em formas específicas de dominação. O uso da Internet no atual contexto econômico, político e social torna-se essencial tanto para o exercício do poder como para oposição a ele.

Este trabalho localiza a busca por legitimação na interface entre política e cultura, e a Internet é um dos meios pelos quais as organizações buscam ampliar suas fronteiras simbólicas, instruindo, informando, agradando e persuadindo de modo a obter endosso para a sua existência, para suas atividades e seus objetivos. Quando as organizações se apresentam como justas e dignas de apoio estão, em circunstâncias específicas, atendendo às exigências de legitimação, no que estas podem ser mais ou menos efetivas.

Desde os anos 90, a Web se constitui em um domínio discursivo, um espaço para as práticas humanas e as ações institucionais (GALLI, 2004; MELO, 2004). No ambiente virtual, as organizações mobilizam símbolos para criar, manter e ou ampliar poder. As "formas simbólicas" constituem um amplo espectro de ações, falas, imagens e textos que são produzidos por sujeitos e reconhecidos por eles e outros como significativos. O uso de significado/sentido a serviço do poder para criar e manter uma situação de dominação caracteriza-se como ideologia. Conforme Thompson (2002, p. 76, grifo do autor), "fenômenos ideológicos são fenômenos simbólicos significativos desde que sirvam, em circunstâncias sócio-históricas específicas, para estabelecer e sustentar relações de dominação", ou seja, relações assimétricas de poder.

O discurso ideológico, para Chaui (2001), visa a realizar a lógica do poder fazendo com que as divisões e as diferenças apareçam como simples diversidade das condições de vida de cada um, e a multiplicidade das instituições aparece não como uma multiplicidade conflituosa, mas um conjunto de esferas harmoniosa e funcionalmente entrelaçadas, ocultando a divisão, a diferença e a contradição. Para essa autora, é desse processo de universalizar o particular que a ideologia ganha coerência e força. O discurso ideológico é um discurso lacunar, que não pode ser preenchido, visto que os termos ausentes garantem a suposta veracidade daquilo que está explicitamente afirmado.

A linguagem não é ingênua no discurso autorizado ou burocrático-institucional, segundo Citelli (2004), e os recentes modos de dizer podem estar escondendo novas formas de organizar a sociedade. Em Administração muitos termos são criados, quase sempre, para minimizar fenômenos socialmente difíceis de serem tratados: "reengenharia", "racionalização das empresas", "flexibilização das leis trabalhista", "adaptação aos mercados globalizados". Esses termos podem estar dizendo, simplesmente, "aumento do desemprego", "cortes na folha de pagamento", "retirada de direitos sociais", "aprofundamento de desigualdades sociais entre países ricos e pobres".

A perspectiva de análise crítica do discurso, conforme Fairclough (2001, p. 91), considera que "o discurso é uma prática, não apenas de representação do mundo, mas de significação do mundo, constituindo e construindo o mundo em significado". O discurso é moldado por relações de poder e ideologias, produz efeitos construtivos sobre as identidades sociais, as relações sociais e os sistemas de conhecimento e crença. O termo "discurso" 
refere-se, segundo o autor, ao uso da linguagem como forma de prática social - e práticas sociais são compreendidas a partir dos conceitos de ideologia e hegemonia. As hegemonias em organizações e instituições particulares, e no nível societário, são produzidas, reproduzidas, contestadas e transformadas no discurso. Essa concepção dinâmica da prática discursiva pressupõe a intertextualidade: textos são constituídos a partir de fragmentos de outros textos, historicidade que lhes proporciona papel central na preservação ou mudança da estrutura social e política. Por isso, Fairclough (2001) propõe uma análise tridimensional do discurso, que envolve o texto, a prática discursiva e a prática social.

Ainda na perspectiva de análise crítica do discurso, Dijk (2006) discute as diferenças entre o discurso persuasivo e o discurso manipulativo. Na persuasão, que envolve poder e dominação, os atores são livres para acreditar ou agir como desejarem, ao aceitar ou não os argumentos do persuasor. O que não ocorre com a manipulação. Esta é exercida a partir de três aspectos conectados e necessários: cognitivo (envolve controle da mente e interfere no processo de conhecimento), discursivo (envolve o uso de formas de discurso ideológico) e social (é um fenômeno que envolve interação e abuso de poder entre grupos e atores sociais). Em uma sociedade democrática, afirma o autor, a manipulação é ilegítima porque (re)produz a desigualdade social e viola os direitos dos grupos dominados para favorecer os principais interesses dos grupos dominantes.

Quanto à legitimação, não é tema recente na Sociologia e nos estudos organizacionais. No trabalho de Weber (1991), está relacionada às diferentes formas de poder. Parsons (1976) discutiu a necessidade de a organização, como um sistema de valores e metas, buscar a legitimação a partir do seu lugar ou "papel" no sistema a que se subordina. Perrow (1961) destacou a importância da imagem pública e do prestígio da organização como forma de controlar sua dependência em relação ao ambiente. O interesse pela legitimação organizacional amplia-se com a abordagem de sistemas abertos (SCOTT, 1998) e a necessidade de compreender melhor a relação organização-ambiente. A teoria institucional contribuiu com o desenvolvimento do conceito ao destacar que os imperativos culturais e normativos do ambiente fazem emergir o isomorfismo organizacional (DIMAGGIO; POWELL, 1983; MEYER; ROWAN, 1977).

A visão baseada em recursos (Resource Based-View) considera que há relação entre a base de recursos da firma e o seu desempenho (WERNERFELT, 1997). Portanto, a congruência entre o ambiente e o comportamento organizacional é uma condição para que a organização possa obter suporte societal (DOWLING; PFEFFER, 1975). Outras pesquisas estão relacionadas ao gerenciamento de impressões (GINZEL et al, 1993; MOHAMED et al., 1999) e à abordagem de stakeholders (FREEMAN; REED, 1983; MITCHELL et al., 1997). Um aspecto comum a estas duas abordagens é a preocupação com a audiência ou o público com o qual a organização interage, enfatizando que a legitimação é um aspecto-chave do processo de gestão.

Outros estudos no campo estão relacionados aos processos discursivos que envolvem a legitimação organizacional (COUPLAND; BROWN, 2004; LIVESEY, 1999, 2002a, 2002b; POLLACH, 2003). Em busca de legitimação, as organizações fazem uso da linguagem e da comunicação empreendendo um processo dinâmico de construção de símbolos, concebidos para legitimar certas idéias, valores e demandas, e "deslegitimar" determinadas demandas, interesses e comportamentos (CLEGG, 1987; ELSBACH; SUTTON, 1992). Porém, a busca por gerar e manter legitimação pode levar a organização a obter efeito oposto àquele desejado (ASHFORTH; GIBBS, 1990). Os relacionamentos entre textos, discurso, instituições e ações são explorados por Phillips, Lawrence e Hardy (2004), em busca de um modelo de institucionalização que considere o papel do discurso. Uma visão geral de questões ontológicas e epistemológicas sobre o conceito é apresentada por Hybles (1995).

Neste artigo, adota-se a definição de legitimação organizacional proposta por Suchman (1995, p. 574), ou seja, "uma percepção generalizada ou pressuposição de que as ações de uma entidade são desejáveis, adequadas [dignas] ou apropriadas conforme um sistema socialmente construído de normas, valores, crenças e idéias". A legitimação é adquirida objetivamente, contudo, criada subjetivamente, isto é, representa uma reação dos observadores (audiência coletiva) em relação ao modo como eles vêem aquela entidade. Por ser independente de observadores particulares, a organização pode se desviar de valores individuais e, ainda assim, obter legitimação, porque esse desvio não gerou uma desaprovação pública. Suchman (1995) identificou três tipos ou 
formas de legitimação organizacional: a legitimação pragmática (tem como base o cálculo auto-interessado de uma organização sobre sua audiência imediata), a legitimação moral (tem como base uma avaliação normativa positiva da organização, ou julgamento de suas atividades como sendo "a coisa certa" para se fazer) e a legitimação cognitiva (tem como base a compreensibilidade e a atribuição de um status taken-for-granted para a organização).

A presente pesquisa se interessa, também, pelo modo como as companhias constroem simbolicamente a legitimação organizacional. Nos anos 70, Halliday (1987) analisou a retórica de multinacionais a partir do estudo de anúncios publicados em periódicos selecionados, dirigidos para três países: Brasil, Estados Unidos e França. Esta autora identificou que as empresas assumiam papéis e faziam uso de personae. A personificação é uma estratégia lingüística que visa a estabelecer uma personalidade para a empresa e torná-la persona grata. As empresas faziam uso de três personae, alterando "quem eu sou" conforme o país-destino da mensagem: a Parceira, que se define pela utilidade; a Compatriota/Irmã-em-humanidade, que se define pela compatibilidade; e a Encarregada-de-uma-grande-missão, que se define pela transcendência. Conforme Cheney et al. (2004), os estudos retóricos vêm enfatizando a persuasão como um processo dialético que considera os atores sociais, $o$ texto e a situação em que a comunicação ocorre.

A perspectiva crítica de análise do discurso (DJIK, 2006; FAIRCLOUGH, 2001) destaca a necessidade de que o texto e as práticas discursivas sejam analisados em um contexto de práticas sociais. Portanto, é preciso compreender aspectos-chave da situação retórica das companhias. A análise do texto, quando associada à análise do contexto, indica um processo de intertextualidade, ou seja, como o texto é moldado por textos anteriores aos quais ele está "respondendo" e por textos subseqüentes que "ele" antecipa. Segundo Fairclough (2001), objetos e sujeitos são moldados por práticas discursivas, mas essas práticas são constrangidas por uma realidade material, constituída por objetos e sujeitos sociais pré-constituídos. Disso decorre que o impacto da prática discursiva depende de como esta interage com a realidade pré-constituída, podendo constituir-se em fator de reprodução ou transformação social. A seguir, são destacados alguns aspectos da situação retórica das empresas, para que se possa identificar a audiência real do discurso e compreender a exigência (acordo prévio) à qual a retórica responde.

\section{A situação retórica das empresas}

O século XXI emerge como um momento em que as fronteiras entre organização e ambiente estão mais porosas e problemáticas, visto que aos imperativos econômicos e tecnológicos do ambiente somam-se requisitos culturais, político-legais e morais, fazendo emergir um complexo de relações entre as organizações e seus diferentes públicos-alvo. No atual contexto de negócios, as organizações adotam práticas de gestão como reengenharia, produção flexível, terceirização, downsizing e contratos temporários de trabalho. O processo de mudança patrimonial conduzido pelas empresas se intensificou nos anos 1980 e 1990, com as estratégias de fusões e aquisições em todo o mundo (UNCTAD, 2005). Tais processos e técnicas de gestão alteram de forma significativa três aspectos: quem executará as atividades, o tipo de atividade a ser realizada na empresa e o modo como serão realizadas pelos membros da organização.

O uso das novas tecnologias de comunicação pelas empresas possibilitou mudanças no modo de acesso aos recursos, nas formas de realização das atividades produtivas e nas formas de venda e entrega dos produtos e serviços. Essas tecnologias também possibilitaram a emergência de novos competidores, pequenas e médias empresas ponto.com, que passam a atuar em determinados nichos de mercado. Nesse contexto, o processo de criar, estabelecer e gerenciar imagens e percepções a partir dos quais o público-alvo percebe, acredita e avalia as organizações passa a ser fator-chave para a moderna gestão.

Segundo Klein (2002), nas últimas décadas, as empresas reconsideraram suas estratégias de marketing. A idéia segundo a qual a empresa vende um produto é substituída nos anos 1980 e 1990, momento a partir do qual o produto passa a ser sempre secundário em relação à marca, e a venda de uma marca adquire um componente adicional que só pode ser descrito como espiritual. Segundo esta autora, enquanto a publicidade trata de apregoar o produto, o brand equit (capital de marca), em suas encarnações mais autênticas e avançadas, trata de 
transcendência corporativa, pois, nas últimas décadas, as empresas não se propõem a vender mercadorias, mas uma idéia, um estilo, um conceito, um sonho.

\section{Quadro 1. O contexto organizacional recente}

\begin{tabular}{ll}
\hline Dimensão de análise & Trabalhos \\
\hline $\begin{array}{l}\text { A crise do modelo econômico do pós-guerra e a } \\
\text { reestruturação produtiva. }\end{array}$ & $\begin{array}{l}\text { Antunes (2000), Harvey (2003), Lipietz } \\
(1989) .\end{array}$ \\
$\begin{array}{l}\text { A emergência de outros modos de vida e formas de } \\
\text { organização social e suas conseqüências. }\end{array}$ & $\begin{array}{l}\text { Castells (2003), Giddens (1991), Harvey } \\
(2003) .\end{array}$ \\
$\begin{array}{l}\text { O processo de globalização e o papel das } \\
\text { Organizações Intergovernamentais - OIGs. }\end{array}$ & Held e McGrew (2001). \\
$\begin{array}{l}\text { A emergência de "novos" atores sociais: os } \\
\text { movimentos anticorporação e antiglobalização. }\end{array}$ & $\begin{array}{l}\text { Gohn (2003), Houtart e Polet (2002), Klein } \\
\text { (2002), Tucker e Melewar (2005). }\end{array}$ \\
As organizações e a gestão contemporânea. & $\begin{array}{l}\text { Alvesson, 1990, Freitas (2002), Gurovitz e } \\
\text { Blecher (2005), Rodrigues (2004). }\end{array}$ \\
\hline
\end{tabular}

Fonte: elaborado pelos autores

Essas mudanças no âmbito das organizações ocorrem em um determinado contexto histórico-social que vários autores vêm buscando compreender, conforme síntese apresentada no Quadro 1. No caso do movimento anticorporação, segundo Klein (2002, p. 465), "essa é uma luta pelo poder”. Os códigos corporativos de conduta não são democraticamente controlados, as empresas não se submetem à autoridade coletiva externa, isso pode parecer irreal, mas é possível e necessário, segundo esta autora. Nos últimos anos, as corporações adquiriram poder sem precedentes, além do mais, não cumpriram as promessas de mais emprego (pois adotam estruturas enxutas na "era do conhecimento"), mais espaço (pois as companhias estão em todos os lugares devido às parcerias-público privadas e às estratégias de patrocínio) e mais opções (pois cresce o número de fusões e aquisições).

Em tal contexto, a organização burocrática também é questionada. Ainda que as críticas à burocracia e ao sistema taylorista-fordista sejam variadas e anteriores aos anos 1970 é, sobretudo, nos anos 1980 e 1990, que se fala de uma "nova" organização mais adequada à "nova economia" (CASTELLS, 2003). Para Rodrigues (2004), quatro desafios são colocados para a Administração no século XXI: pressões ligadas à globalização, pressões relativas ao controle de custo, pressões relativas à confiança entre os stakeholders, e demandas por um comportamento corporativo ético e responsável. As empresas, no final dos anos 1990 e início dos anos 2000, se vêem pressionadas a elaborar respostas para as críticas e a assumir novos compromissos, buscando, assim, uma inserção mais adequada às condições econômicas e sociais contemporâneas (TUCKER; MELEWAR, 2005). Também, gradualmente, "vem-se formando um consenso de que a sobrevivência da empresa no longo prazo depende da construção de uma relação mais equilibrada com seus vários stakeholders" (RODRIGUES, 2004, p. 110).

As empresas são sistemas complexos que se adaptam, mas também transformam o contexto no qual "fazem a vida". A linguagem constitui um dos elementos importantes desse processo; primeiro, porque a empresa precisa comunicar o que pretende; segundo, porque se trata de um processo reflexivo de criação de uma nova representação da empresa para diferentes públicos. A decisão sobre quais temas irão ancorar o discurso organizacional, em determinado espaço e tempo, pressupõe que as empresas saibam "ler" o ambiente em que atuam e possam (re)elaborar respostas de maneira funcional, e também simbólica.

Isso implica que as organizações construam para si e de si uma imagem que possa se enraizar em imaginário próprio e ser repassada aos seus públicos-chave. Em Alvesson (1990), vemos como a imagem se torna um 
objeto sistemático de controle na gestão contemporânea. Para Freitas (2002, p. 39), "as instituições sociais ganham e perdem espaços de poder na dinâmica da própria sociedade, no seu constante refazer-se e na luta das forças que ela própria abriga". Em relação a qual imagem as organizações criaram para si, nos anos recentes, a autora afirma que há uma tendência das empresas de se auto-afirmarem como a organização social por excelência, a partir de uma imagem grandiosa sustentada por cinco temas: cidadania, excelência, empresa lugar da juventude eterna, ética e moralidade e a idéia de empresa-comunidade.

No caso brasileiro, Gurovitz e Blecher (2005) apontaram a contradição entre as percepções e expectativas que a população brasileira, de um lado, e os empresários e executivos, de outro, têm em relação à razão de ser das empresas. Para os empresários entrevistados, a razão de ser da empresa é dar lucro aos acionistas, enquanto a pesquisa de opinião pública aponta que é gerar empregos. Embora tal resultado indique uma contradição entre as expectativas da população brasileira e as expectativas dos empresários e executivos, a presente pesquisa sugere que contradição e ambigüidade são parte da relação empresa-ambiente. A retórica da empresa contribuirá no sentido de encorajar a audiência a esquecer essas ambigüidades e contradições, ou a não vê-las como tal, tornando-se, assim, um elemento fundamental para a gestão das organizações contemporâneas. A seção seguinte discute os procedimentos da análise retórica empreendida neste artigo.

\section{Procedimentos metodológicos}

Esta pesquisa busca compreender, a partir de uma análise das autodescrições das empresas em seus websites, como estas usam intencionalmente a linguagem e mobilizam simbologias em busca de legitimação. Em relação à retórica, serão analisados quais personae as empresas assumem e os lugares-tema que se constituem a fonte para os argumentos do discurso organizacional. Em relação às formas de legitimação, se examinará de que modo as empresas pesquisadas buscam a aprovação e o apoio para a sua existência e seus objetivos, conforme Figura 1.

As dimensões de análise desta pesquisa são a cultura e o poder na comunicação organizacional, tendo como unidade de análise o discurso oficial das empresas na Web. A categoria de análise é a autodescrição (autoafirmação), por parte das empresas, presente em seu website. A seleção das empresas foi intencional e, como critério para tal, utilizou-se a seleção de empresas "Maiores e Melhores" pelo Anuário "As 500 Maiores Empresas do Brasil", da revista Exame, de julho de 2004. Esta pesquisa, realizada de 27/08/2004 a 15/01/2005, restringe-se à análise de textos, embora imagens e sons sejam utilizados pelas empresas em seus websites.

\section{Figura 1. Parâmetros para a análise da legitimação organizacional}

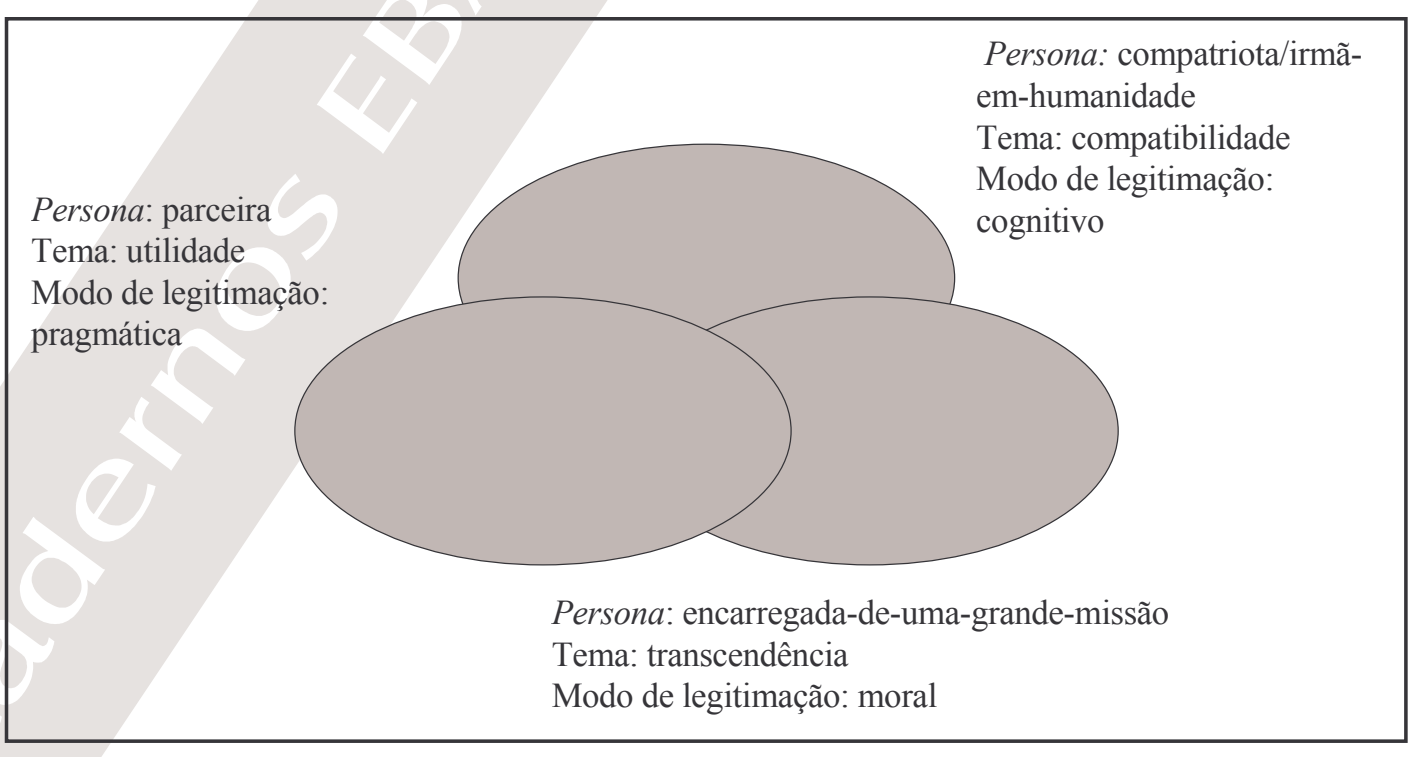

Fonte: elaborada pelos autores, a partir de Halliday (1987) e Suchman (1995). 
O principal método de procedimento utilizado foi a análise retórica e, como apoio, alguns pressupostos da análise crítica do discurso. A análise retórica de textos e discursos orais investiga, segundo Leach (2002), como e por que eles são atrativos e persuasivos, por que eles se desenvolveram em momentos específicos, e quais estruturas de argumentação e princípios estruturantes estão em ação. A pesquisa sobre discurso organizacional tem como base que os textos se constituem e são constituídos em e por organizações. A análise do discurso não é vista apenas como uma metodologia, mas uma forma de compreensão da organização e de seus processos de gestão, visto que os textos constituem uma importante forma de ação social (GRANT; KEENOY; OSWICK, 2001; HARDY, 2001). Conforme Cheney et al. (2004), a análise retórica e a análise crítica do discurso propiciam uma abordagem complementar ao estudo da linguagem em organizações, pois enquanto a retórica tem a persuasão e a identificação como aspectos centrais, a análise crítica do discurso orienta-se para o conceito de poder.

Os procedimentos para a análise retórica tiveram como base Aristóteles [19-], Leach (2002), Perelman e Olbrechts-Tyteca (1996), Reboul (2000). A pesquisa nos sites considerou os links nos quais havia uma autodescrição das empresas: ramo de atividades, visão, missão, valores, objetivos, história da empresa, suas relações com clientes, fornecedores, investidores, colaboradores, comunidade e sociedade. Nem todas as empresas apresentam links específicos para essas informações, que podem estar "misturadas" em um texto.

Inicialmente, realizou-se uma pesquisa piloto com seis empresas, o que permitiu a elaboração de um esboço dos temas mais freqüentes e dos elementos presentes, mas, à medida que novas consultas foram realizadas, novos elementos surgiam. Na metade da pesquisa, chegou-se a um conjunto de argumentos comuns, ainda que sempre fosse questionada a ausência de elementos identificados na análise da situação retórica. Algumas vezes, foi necessário retornar ao site das empresas para confirmar determinada informação. Para lidar com a grande quantidade e fragmentação de informação, adotou-se como critério restritivo as consultas apenas aos links em que as empresas se autodescreviam aos seus diferentes públicos.

A análise das afirmações autodescritivas das empresas pesquisadas foi conduzida a partir da abordagem histórico-cultural do discurso de Chaui (2001), da perspectiva da Análise Crítica do Discurso de Fairclough (2001) e da perspectiva histórico-social de análise da ideologia e do papel dos meios de comunicação na cultura moderna de Thompson (2002). A análise crítica do discurso envolve duas instâncias: a descritiva, relacionada ao texto, e a interpretativa, relacionada às práticas discursivas.

Este trabalho, considerando os pressupostos da Análise Crítica do Discurso (FAIRCLOUGH, 2005), adota o realismo crítico como ontologia e uma epistemologia analiticamente dualista, que considera tanto o realismo crítico quanto uma abordagem moderada do construtivismo social. Tal posição impede que se adote uma perspectiva da organização como discurso ou como texto, pois o estudo das organizações não pode ser reduzido ao estudo do discurso. As relações entre agência e estrutura são consideradas tendo em vista a mudança organizacional. Nesse sentido, o discurso da organização e os de seus diferentes públicos constituem práticas sociais que mobilizam simbologias e podem transformar valores, crenças e comportamentos.

\section{As empresas na Web: retórica em busca de legitimação organizacional}

Segundo os antigos, a retórica diz respeito aos discursos persuasivos: judiciário, deliberativo e epidíctico. O discurso das "Melhores e Maiores" na Web é epidíctico, "pois o orador propõe-se à admiração dos espectadores" (REBOUL, 2000, p.46), por meio de argumentos que exaltam suas qualidades, importância, nobreza, méritos e cala-se sobre o vício, o disforme e o que pode levar à censura. As virtudes tornam alguém digno de confiança, "o belo é o que, sendo preferível por si, é digno de louvor, ou o que, sendo bom, é agradável pelo fato de ser bom", conforme Aristóteles [19-, p. 7].

Ao contrário do discurso judiciário (dos tribunais) e do discurso deliberativo (dos políticos e legisladores), o discurso epidíctico ou demonstrativo é persuasivo no longo prazo, pois, ainda que não exija uma decisão imediata, orienta escolhas futuras, é um discurso essencialmente pedagógico, conforme Perelman e Olbrechts- 
Tyteca (1996). Este gênero do discurso permite que as grandes empresas existam como organização e exerçam seu poder para além da oferta de bens ou serviços, da maneira mais lucrativa possível. Para tal, as empresas necessitam negociar a latitude das suas fronteiras físicas, políticas, legais, econômicas, culturais e morais (HALLIDAY, 1987). A seguir, discutem-se os elementos estruturantes dos discursos das empresas na Web.

\section{Quem fala? Quando? Contra o quê? Por quê? Como?}

As perguntas preliminares para uma análise retórica que dizem respeito ao orador são: Quem fala? Quando? Contra o quê? Por quê? Como? Na presente pesquisa, conforme dito anteriormente, a seleção das empresas pesquisadas teve como base o Anuário "As 500 maiores empresas do Brasil: melhores e maiores", de julho de 2004, publicado pela revista Exame. Além de um ranking das 500 maiores empresas do Brasil, o anuário também identifica as melhores e as maiores por setor. O presente trabalho considerou a "Melhor" e a "Maior" de 20 setores, logo, "quem fala" são as 40 empresas privadas de capital nacional e estrangeiro e empresas estatais, de diferentes setores, indicadas maiores e melhores de 2004.

No que se refere a "quando", a pesquisa nos websites das empresas selecionadas ocorreu no período de 27/08/2004 até 15/01/2005. De modo mais amplo, trata-se do discurso organizacional de empresas brasileiras no início do século XXI. A questão "contra o quê?" refere-se aos críticos e aos movimentos antiglobalização e anticorporação (KLEIN, 2002) e às pressões relacionadas à globalização, ao controle de custos, às pressões por maior confiança entre os stakeholders e às demandas por um comportamento corporativo ético e responsável (RODRIGUES, 2004) que caracterizam o atual contexto empresarial. Esses aspectos associados às mudanças organizacionais e institucionais e às transformações no contexto social mais amplo geram incerteza e conflito no ambiente de negócios.

Quanto à questão "por que", o discurso das empresas tende a persuadir compradores, clientes, governos, investidores, funcionários, a comunidade etc. de que a empresa está preparada para enfrentar tais desafios, objetivo imediato. Mas, segundo Reboul (2000), o discurso tende a persuadir de algo que pode ser múltiplo e o texto, muitas vezes, tem um objetivo imediato e outro distante. Nesse caso, o objetivo de longo prazo é persuadir os públicos-alvo de que a empresa apresenta-se como a instituição social por excelência, ator central da sociedade que fornece o modelo de referências predominantes para o conjunto dos comportamentos coletivos (FREITAS, 2002).

Em relação a "como" o orador se manifesta, as empresas tendem a se apresentar como persona grata, cuja "beleza" e "virtude" são dignas de louvor, simpatia e apoio, assumindo diferentes papéis e buscando argumentos em temas como utilidade, compatibilidade e transcendência (HALLIDAY, 1987). Também são analisados os modos pelos quais as empresas buscam a legitimação organizacional (SUCHMAN, 1995). Esta pesquisa considerou, ainda, as lacunas no discurso (CHAUI, 2001) das empresas, ou seja, a ausência de elementos que possam comprometer a imagem grandiosa que as organizações constroem acerca de si mesmas (FREITAS, 2002).

\section{Como as empresas se autodescrevem em seus websites}

A retórica é constituída por quatro partes: a invenção (busca de todos os argumentos e outros meios de persuasão), a disposição (organização interna do discurso), o estilo (redação do discurso) e a ação (todos os aspectos que envolvem o ato de proferir o discurso). Este estudo se concentra na invenção, em detrimento das demais partes. Esta, por sua vez, constitui-se de três tipos de argumentos: ethos, pathos e logos, além de provas, dos lugares-temas e das personae. A Tabela 1 sintetiza os elementos e as estratégias de comunicação que as empresas pesquisadas utilizam. Devido à grande quantidade de informações, serão discutidos, a seguir, apenas os argumentos relacionados à identidade, aos objetivos-compromissos e às vantagens oferecidas.

As 40 empresas pesquisadas se autodefiniram como Parceiras. A função desta persona é destacar a organização entre competidores e agradar a clientes atuais ou potenciais, com apelos aos benefícios que estes podem obter das empresas, assim, as companhias se tornam desejadas. A Nokia afirma que a sua história demonstra que o sucesso nasce de decisões corretas, tomadas no momento certo. A empresa tem certeza de que essa visão, aliada à coragem de criar novas oportunidades, é o que lhe permite alcançar seus objetivos: "entramos em uma nova era das comunicações", "hoje em dia, todos nós já conhecemos a importância da mobilidade em nossas 
vidas". Para a empresa, satisfazer o cliente é saber atender às suas necessidades, porém, o mais importante é ter a capacidade de antever necessidades emergentes e criar soluções para atendê-las.

Tabela 1. Elementos e estratégias do discurso das "Melhores e Maiores" de 2004

\begin{tabular}{|c|c|c|c|}
\hline Elementos & Estratégias & $\begin{array}{c}\text { N. de } \\
\text { empresas }\end{array}$ & Percentual \\
\hline \multirow{6}{*}{$\begin{array}{l}\text { Credenciais (Ethos: argumentos } \\
\text { vinculados ao caráter moral que o } \\
\text { orador deve assumir para inspirar } \\
\text { confiança, credibilidade e simpatia) }\end{array}$} & Origem & 13 & $33 \%$ \\
\hline & Identidade & 40 & $100 \%$ \\
\hline & Capacidade & 40 & $100 \%$ \\
\hline & Realizações & 40 & $100 \%$ \\
\hline & Atuação/estratégia & 40 & $100 \%$ \\
\hline & Objetivos-compromissos & 40 & $100 \%$ \\
\hline \multirow{6}{*}{$\begin{array}{l}\text { Apelos (Pathos: argumentos } \\
\text { vinculados às características } \\
\text { psicossociais do auditório de modo } \\
\text { a suscitar emoções, paixões, } \\
\text { sentimentos) }\end{array}$} & Valores & 40 & $100 \%$ \\
\hline & Crenças & 21 & $53 \%$ \\
\hline & Sentimentos & 18 & $45 \%$ \\
\hline & Opiniões & 31 & $78 \%$ \\
\hline & Alusões & 37 & $84 \%$ \\
\hline & Vantagens & 40 & $100 \%$ \\
\hline \multirow{7}{*}{$\begin{array}{l}\text { Auto-afirmações } \\
\text { cativantes (Logos: argumentos de } \\
\text { ordem racional que buscam a } \\
\text { amplificação ou a valorização } \\
\text { qualitativa da empresa) }\end{array}$} & A empresa é a única que faz & 12 & $30 \%$ \\
\hline & $\begin{array}{l}\text { Foi a primeira ou está entre as } \\
\text { primeiras (pioneira) }\end{array}$ & 30 & $75 \%$ \\
\hline & $\begin{array}{l}\text { É a melhor ou está entre as } \\
\text { melhores (está entre as poucas que } \\
\text { fazem) }\end{array}$ & 22 & $55 \%$ \\
\hline & $\begin{array}{l}\text { É a que faz ou oferece mais ou está } \\
\text { entre (líder) }\end{array}$ & 22 & $55 \%$ \\
\hline & É a maior ou está entre as maiores & 32 & $80 \%$ \\
\hline & Faz muito (experiência) & 20 & $50 \%$ \\
\hline & Recebeu prêmios e homenagens & 26 & $65 \%$ \\
\hline \multirow{4}{*}{$\begin{array}{l}\text { Provas (argumentos de } \\
\text { reforço e testemunhas) }\end{array}$} & Certificados e selos & 26 & $65 \%$ \\
\hline & Números e relatórios & 27 & $68 \%$ \\
\hline & A empresa na imprensa & 26 & $65 \%$ \\
\hline & Código de conduta/ética & 12 & $30 \%$ \\
\hline \multirow{3}{*}{$\begin{array}{l}\text { Temas (lugares-temas a partir dos } \\
\text { quais se retiram os argumentos) e } \\
\text { Personae (recurso lingüístico que } \\
\text { visa a tornar a empresa persona } \\
\text { grata) }\end{array}$} & Utilidade - Parceira & 40 & $100 \%$ \\
\hline & $\begin{array}{l}\text { Compatibilidade - Moderna/Irmã- } \\
\text { em-humanidade }\end{array}$ & 33 & $83 \%$ \\
\hline & $\begin{array}{l}\text { Transcendência - Encarregada-de- } \\
\text { uma-grande-missão }\end{array}$ & 33 & $83 \%$ \\
\hline
\end{tabular}

Fonte: elaborada pelos autores, a partir de Aristóteles [19-], Halliday (1987), Leach (2002), Perelman e OlbrechtsTyteca (1996), Reboul (2000) e da pesquisa nos sites das empresas.

A persona Moderna/Irmã-em-humanidade é utilizada por $83 \%$ das empresas pesquisadas, e tem a função de criar uma comunhão de propósitos e de interesses com seus públicos-alvo. Tal persona espera ser compreendida por demonstrar compatibilidade com as demandas do atual contexto de negócios. Essa relação de intimidade está presente no site da Unilever. A empresa afirma que conhece profundamente o Brasil e procura corresponder à expectativa de bem-estar e qualidade de vida cotidiana dos brasileiros, acompanhando o amadurecimento do consumidor brasileiro ao longo de gerações. Como a intimidade depende do outro, a 
Unilever argumenta que uma pesquisa realizada em 2000 indicou que $100 \%$ dos brasileiros conhecem e utilizam, por dia, pelo menos um produto da Unilever.

A autodefinição da empresa como Encarregada-de-uma-grande-missão está presente em $83 \%$ dos websites pesquisados. Esta persona é idealista, altruísta e socialmente engajada. E seus atributos sacramentam a empresa, aliando-a a fins mais elevados e preparando-a, assim, para dirigir-se a uma audiência universal. Sua função é apaziguadora, por despertar a admiração e o respeito da audiência. A Albrás fala do seu programa "Sorriso nos Rios", realizado em parceria com diversas entidades e funcionários-voluntários da empresa. Estes últimos desenvolveram equipamentos de proteção para os eixos dos barcos que navegam nos rios da região em que está situada a Albrás. Os equipamentos foram implantados gratuitamente para prevenir o escalpamento de crianças (em geral, meninas) que, brincando em pequenos barcos, deixam o cabelo ser atingido pelos eixos dos motores. A Construtora Odebrecht fala de seu "Projeto Reinserção Social" dirigido aos mutilados de guerra em Angola que trabalham na Hidrelétrica de Capanda. A empresa ressalta que esses funcionários recebem o mesmo salário dos demais integrantes de funções correlatas e apresenta depoimentos de três pessoas beneficiadas pelo projeto. Essa companhia destaca, ainda, o "Programa de Combate à Aids", em Angola, premiado internacionalmente.

A identidade é elemento-chave do ethos organizacional e a resposta para "quem eu sou" altera-se dependendo da persona que fala, conforme Quadro 2. Em seus websites, as empresas se expressam para uma audiência universal, o que não implica ausência de públicos-alvo, fato que pode ser comprovado com uma consulta ao mapa do site. Ali, são encontrados os links dirigidos aos compradores, acionistas, funcionários, sociedade e outros. As múltiplas vozes permitem que a empresa se comunique com grupos que possuem interesses muito diferentes e conflitantes em relação à organização. Nesse sentido, a contradição e/ou a ambigüidade do discurso organizacional são aspectos que, para serem amplamente compreendidos, exigem a análise da retórica dessas diferentes personalidades (CHENEY et al., 2004).

Quadro 2. As identidades das "Melhores e Maiores" (número de empresas)

\begin{tabular}{|c|c|c|c|c|c|}
\hline Parceira & & \multicolumn{2}{|c|}{ Moderna/Irmã-em-humanidade } & \multicolumn{2}{|c|}{$\begin{array}{l}\text { Encarregada-de-uma-grande- } \\
\text { missão }\end{array}$} \\
\hline \multirow{8}{*}{$\begin{array}{l}\text { Somos excelentes } \\
\text { Podemos ajudar você } \\
\text { Somos inovadoras } \\
\text { Somos } \\
\text { admiradas/reconhecidas } \\
\text { (marcas consagradas) }\end{array}$} & 40 & Somos modernas & 37 & Temos altos ideais & 35 \\
\hline & 40 & Somos competitivas & 37 & Somos socialmente & \\
\hline & 37 & Fazemos parte da sua vida & 21 & responsáveis & 33 \\
\hline & & Somos como você & 21 & Somos ecologicamente & \\
\hline & 28 & Somos éticas & 20 & responsáveis & 33 \\
\hline & & Somos vencedoras, bem- & & Somos empresa-cidadã & 28 \\
\hline & & sucedidas & 16 & Somos uma comunidade & 25 \\
\hline & & Somos empresas globais & 11 & & \\
\hline
\end{tabular}

Fonte: elaborado pelos autores, a partir da pesquisa nos sites das empresas.

Aristóteles [19-, p. 81], ao falar do discurso panegírico ou epidíctico, afirma que este tem por objeto as ações, "os atos são os sinais das disposições da alma" e "as obras são sinais de virtude"; trata-se de ações e obras realizadas deliberadamente, já que "é próprio do homem virtuoso agir deliberadamente". Por isso, esta pesquisa considerou os objetivos- compromissos que as empresas retoricamente apresentam na Web. Objetivoscompromissos são estratégias retóricas associadas ao ethos empresarial, denotam o caráter do orador que busca inspirar a confiança da audiência. 


\section{Quadro 3. Objetivos e compromissos das "Melhores e Maiores" (número de empresas)}

\begin{tabular}{|c|c|c|c|c|c|}
\hline \multicolumn{2}{|l|}{ Utilidade } & \multicolumn{2}{|l|}{ Compatibilidade } & \multicolumn{2}{|l|}{ Transcendência } \\
\hline Satisfação dos clientes & 40 & Ser moderna/competitive & 40 & $\begin{array}{l}\text { Produzir transformação social } \\
\text { rumo a uma sociedade mais }\end{array}$ & 31 \\
\hline $\begin{array}{l}\text { Qualidade dos } \\
\text { produtos/serviços }\end{array}$ & 38 & $\begin{array}{l}\text { Alinhamento com as } \\
\text { mudanças do Mercado }\end{array}$ & 34 & justa & \\
\hline $\begin{array}{l}\text { Crescimento/resultado } \\
\text { /lucratividade }\end{array}$ & 34 & $\begin{array}{l}\text { Desenvolvimento dos } \\
\text { funcionários }\end{array}$ & 31 & $\begin{array}{l}\text { Contribuir com a missão de } \\
\text { educar: inserção social, auto- } \\
\text { estima }\end{array}$ & 30 \\
\hline Inovação & 34 & $\begin{array}{l}\text { Reduzir os impactos } \\
\text { ambientais de suas atividades }\end{array}$ & 29 & $\begin{array}{l}\text { Preservação e conservação da } \\
\text { natureza }\end{array}$ & 30 \\
\hline Eficiência & 34 & Oferecer melhores condições & 27 & Construção da cidadania & 6 \\
\hline $\begin{array}{l}\text { Excelência a partir das } \\
\text { melhores práticas }\end{array}$ & 33 & Ações éticas e transparentes & 20 & $\begin{array}{l}\text { Qualidade de vida da } \\
\text { comunidade onde atua }\end{array}$ & 25 \\
\hline $\begin{array}{l}\text { Criar/manter equipes } \\
\text { competentes }\end{array}$ & 32 & & & $\begin{array}{l}\text { Trabalhar para um futuro } \\
\text { melhor/futuras gerações }\end{array}$ & 23 \\
\hline
\end{tabular}

Fonte: elaborado pelos autores, a partir da pesquisa nos sites das empresas.

No Quadro 3, estão sintetizados os objetivos ou fins com os quais as empresas declaram estar operacional e moralmente comprometidas e que indicam o tipo de relacionamento que se pode vir a estabelecer entre empresa e audiência. A IBM, pela voz da Parceira, declara como objetivo manter-se na liderança em criação, desenvolvimento e manufatura das mais avançadas tecnologias de informação da indústria. A empresa diz estar apta a ajudar os "nossos" clientes a enfrentar seus desafios mais complexos, sabe que existe para servir "nossos" consumidores e para fazer "nossos" acionistas felizes.

Pela voz da Moderna/Irmã-em-humanidade, a IBM declara ser uma companhia verdadeiramente global. Poucas companhias têm mais história e mais futuro que a IBM. A companhia afirma que a "nossa" empresa está por toda parte há mais de 90 anos, portanto, tem um legado. Afirma, também, que "nos orgulhamos de nossa habilidade, não simplesmente de inventar grandes coisas, e sim de reinventar a nós mesmos". A empresa explica que, atualmente, o mercado exige flexibilidade e responsividade para a rápida adaptação aos novos modelos de negócios. A empresa compartilha os objetivos-compromissos organizacionais com a audiência, como se dissesse: "são nossos" esses objetivos. Pela voz da Encarregada-de-uma-grande-missão, a companhia declara que está comprometida com a liderança ambiental em todas as suas atividades de negócios, com a comunidade, com a cidadania corporativa e a filantropia. Segundo a IBM, os programas de filantropia são diversos e sustentáveis e se espalham pelo globo, com iniciativas na educação, desenvolvimento da força de trabalho, artes e cultura para o atendimento das necessidades da comunidade.

\section{Análise do discurso das companhias}

Esta pesquisa identificou que os objetivos presentes nos discursos das empresas são múltiplos (variam conforme a persona) e conflitantes (se propõem a atender aos interesses de grupos diferentes). Entretanto, temas que, no discurso das empresas poderiam ser vistos como contraditórios, estão harmonizados no texto. Em parte, isso se deve ao sentido limitado que alguns termos adquirem, por exemplo, cidadania como atendimento de necessidades, educação como treinamento ou educação profissionalizante.

No website da empresa Gol, seu programa de educação visa a atender às necessidades do colaborador, do acionista, dos clientes e da sociedade como um todo, equilibradamente. A preparação para a vida, argumenta a 
empresa, inclui o desenvolvimento da vontade da pessoa de ser sempre melhor, crescer e realizar-se pessoal e profissionalmente. Os tópicos do programa desta empresa são: conceitos da natureza humana, conceitos da empresa, autogerenciamento e Programa $5 \mathrm{~S}$ (ferramenta de gestão que busca eliminar o desperdício). Não parece razoável que tal programa vá desenvolver pessoas e muito menos prepará-las para a vida.

As vantagens estão em argumentos ligados ao pathos e dizem respeito àquilo que o público tem a ganhar com a existência de determinada organização. Quando associadas, no discurso, aos argumentos de realização (o que fez e o que faz) e estratégias (como faz), têm grande poder de persuasão. Conforme o Quadro 4, as empresas pesquisadas oferecem vantagens e, embora nem todas resultem de decisões deliberadas, tendem a ser apresentadas como tal. A Petrobras, pela voz da Parceira, declara que é detentora de uma das tecnologias mais avançadas do mundo para a produção de petróleo em águas profundas e ultraprofundas, fato que lhe proporciona diferencial competitivo no setor de energia e petróleo.

Quadro 4. Vantagens oferecidas pelas "Melhores e Maiores" (número de empresas)

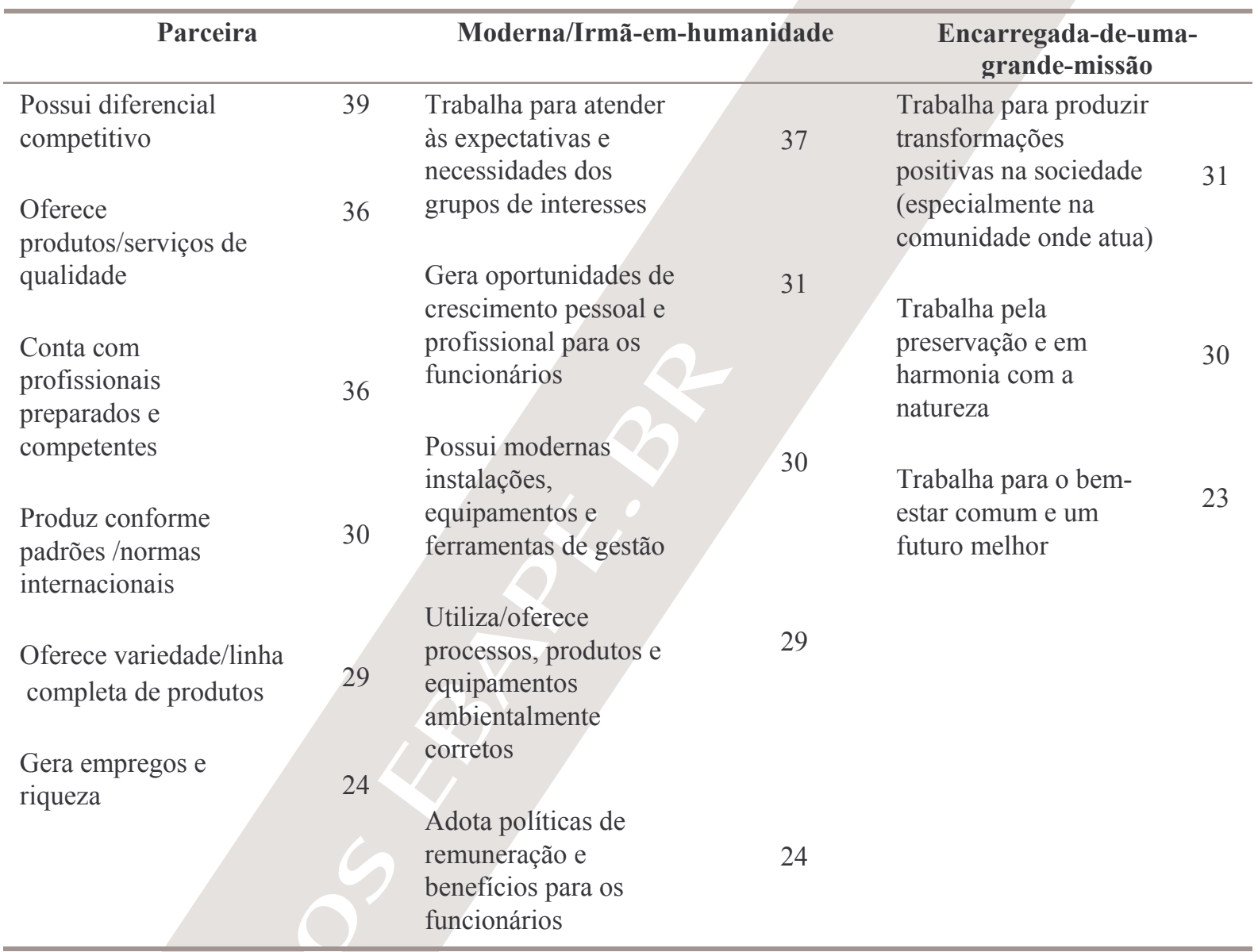

Fonte: elaborado pelos autores, a partir da pesquisa nos sites das empresas.

A Petrobras, pela voz da Moderna/Irmã-em-humanidade, declara que as pesquisas realizadas no Centro de Pesquisa e Desenvolvimento (CENPES) são reconhecidas internacionalmente e posicionam o Brasil entre os países detentores de tecnologia de ponta da indústria do petróleo. Já o Programa Pegaso visa a colocar a Petrobrás na vanguarda das companhias de petróleo em todo o mundo em relação a segurança, meio-ambiente e saúde, visto que, segundo a empresa, as grandes companhias de petróleo preocupam-se muito com a proteção ao homem e ao meio ambiente. Pela voz da Encarregada-de-uma-grande-missão, a Petrobrás se autodefine como uma empresa-cidadã, interessada em cumprir "profundamente" o compromisso da responsabilidade 
social e descreve vários projetos que patrocina e desenvolve, mas não discute que os recursos para alguns desses projetos se devem às leis de incentivo à cultura, por exemplo, o que resulta em renúncia fiscal.

Por fim, ao estabelecermos a triangulação proposta por Fairclough (2001), entre texto, práticas discursivas e contexto social, pôde-se verificar, nesta pesquisa, a ausência de temas que, de algum modo, poderiam gerar dúvidas quanto à beleza e à virtude organizacional e reduzir ou impedir a simpatia e a confiança do público em relação à empresa, o que constitui um discurso lacunar (CHAUI, 2001).

A análise da situação retórica das empresas evidencia alguns temas que não estão presentes em suas autodescrições nos websites, quais sejam: os impactos dos processos de reestruturação sobre o emprego e o uso de novas tecnologias, as conseqüências, para o comprador, das estratégias de fusões e aquisições, como a redução de opções e o aumento do poder das organizações. As empresas não falam de demissões em massa, mas duas, Weg (no início dos anos 1980) e Volkswagen (janeiro de 1999), falam do esforço que fizeram para não demitir. As ações de responsabilidade social e ambiental são tratadas, em geral, como ações desinteressadas e voluntárias, de modo que as vantagens destas ações para a empresa não são apontadas.

Nos websites, as empresas pesquisadas tratam estratégias de internacionalização, alianças, fusões e aquisições como eventos naturais na "vida" de uma organização que quer ajudar, crescer, ser bem-sucedida, e como projetos que vão beneficiar funcionários, clientes, sociedade e governo; quanto aos benefícios para a empresa, estes não são claramente apresentados. Essa é uma estratégia típica da busca por legitimação, segundo Thompson (2002), ou seja, a universalização dos benefícios resultantes de acordos institucionais servem aos interesses de alguns indivíduos, mas são apresentados como servindo aos interesses de todos.

E, por fim, não são citadas as críticas de ativistas, dos consumidores e da sociedade de modo geral quanto ao tipo de produto ou serviço que estas empresas oferecem ou quanto ao modo como estes são produzidos; não são discutidos os acidentes de trabalho, os danos ao meio ambiente, greves de funcionários, manifestações da sociedade civil contra as ações, objetivos, tecnologia ou a existência da empresa. Apenas uma empresa, a Aracruz (do setor de papel e celulose) menciona enfrentar problemas com ativistas. Embora não se tenha feito uma análise mais detalhada destes elementos ausentes, os aspectos acima citados evidenciam o sentido final monofônico (MELO, 2004) do discurso organizacional, por não abrigar em seu interior posicionamentos discursivos desfavoráveis.

\section{Contribuições da pesquisa}

A relevância da Web como espaço-chave na sociedade contemporânea para a articulação de questões sociais exige que a Administração conheça melhor como as empresas se autodefinem neste espaço, como se apropriam dele e empreendem ali processos de busca por legitimação. Esta pesquisa identificou que as empresas se autodefinem em seus websites de três modos: Parceira, Encarregada-de-uma-grande-missão, Moderna/Irmãem-humanidade. Cada persona busca os argumentos para o seu discurso em um lugar-tema: "utilidade", "transcendência" e "compatibilidade", respectivamente. Ainda, cada persona privilegia um modus operandi em sua busca por legitimação: pragmatismo, moralidade e cognição, respectivamente.

A persona Parceira utiliza os argumentos da excelência e da flexibilidade. Respectivamente, fala da busca pela superação dos padrões de qualidade sem que se entreveja um limite para tal e da sua capacidade de renovação ou reinvenção contínua, do seu dinamismo e capacidade para oferecer o que há de mais moderno. Todas as empresas pesquisadas - independente das diferenças entre elas - utilizam o tema "utilidade". A Parceira estabelece um diálogo com a audiência a partir de argumentos vinculados ao auto-interesse, o que indica o pragmatismo (SUCHMAN, 1995) como modus operandi desta persona. A lógica argumentativa destaca as conseqüências positivas visíveis dos produtos e serviços oferecidos para o bem-estar da audiência (o autointeresse da empresa e da audiência), que se constitui prioritariamente de clientes, acionistas e potenciais investidores.

A persona Encarregada-de-uma-grande-missão utiliza argumentos relacionados à cidadania, à comunidade e à responsabilidade sócio-ambiental. As companhias se apresentam como alguém que cumpre os seus deveres e 
se esforça para que os outros também exerçam seus direitos e deveres. Elas afirmam que buscam fortalecer os laços sociais com os funcionários, seus familiares e moradores locais e, desse modo, criam uma coletividade em torno de si. Quanto à responsabilidade sócio-ambiental, são argumentos de alguém que responde legal ou moralmente pela vida e pelo bem-estar de outro, incluindo o meio-ambiente. Isso demonstra que o discurso organizacional ajusta-se e move-se em um campo em transformação. Na medida em que determinados valores se consolidam nesse contexto, cidadania, direitos civis e responsabilidade corporativa, por exemplo, o discurso das empresas atualiza-se com esses valores emergentes. Trata-se, portanto, de um discurso cujas palavras se ajustam ao tempo-espaço, pois está inserido em um contexto sócio-histórico, também diz respeito à inserção da história no texto (FAIRCLOUGH, 2001).

O tema "transcendência" foi empregado por $83 \%$ das 40 empresas pesquisadas. O que parece indicar que a personificação da empresa em Encarregada-de-uma-grande-missão seja um papel importante para que as empresas se tornem persona grata, no atual contexto de negócios. Na análise de Halliday (1987), o tema "transcendência" estava ausente dos discursos das multinacionais e das empresas locais "em casa", o que, segundo a autora, parecia indicar tratar-se de tema peculiar ao discurso das multinacionais, dirigido a uma audiência internacional. Talvez, por tratar-se de discurso veiculado por um meio que atinge uma "audiência universal" e devido ao grau de internacionalização que caracteriza este grupo de empresas, o tema "transcendência" esteja presente, atualmente, nos discursos de tantas empresas.

Esta pesquisa, entretanto, permite concluir que a persona Encarregada-de-uma-grande-missão não é peculiar ou exclusiva das multinacionais quando estas se dirigem a uma audiência internacional. A análise da situação retórica das empresas aponta nesse sentido: um ambiente de negócios caracterizado pela incerteza e por conflitos, vários escândalos corporativos protagonizados por grandes empresas, casos de corporações acusadas, por ativistas, de violação dos direitos humanos em países em desenvolvimento, com destaque na mídia televisiva, no cinema e na Internet, além das informações dos próprios organismos internacionais indicando que vivemos em mundo de enormes desigualdades sociais.

Nesse contexto, as empresas estão mais vulneráveis e têm buscado a legitimação para a sua existência e de seus objetivos no tema "transcendência", mesmo no caso de o discurso se dirigir ao público do país de origem da empresa. A legitimação moral (SUCHMAN, 1995) foi identificada por esta pesquisa como modus operandi da persona Encarregada-de-uma-grande-missão, cuja lógica de argumentação é pró-social. A empresa mostra que está preparada para a avaliação de uma audiência universal.

A persona Compatriota/Irmã-em-humanidade estabelece um diálogo com sua audiência por meio de argumentos que mostram sua flexibilidade e disposição para criar e desenvolver-se a partir do que há de mais moderno em termos de gestão. Combina argumentos que destacam a sua capacidade de renovação e reinvenção contínuas rumo a um futuro de sucesso; ao mesmo tempo, argumenta a favor da ética e da moralidade em seus relacionamentos (alguém que estabelece relações que se fundamentam em princípios éticos e morais). Esses argumentos têm como lugar-tema a "compatibilidade", que está presente no discurso de $83 \%$ das empresas pesquisadas. A análise desta persona, neste início de século, quando confrontada com o estudo de Halliday (1987) na década de 70, indica que a Compatriota/Irmã-em-humanidade está cedendo espaço para uma outra: a Moderna/Irmã-em-humanidade. Essa "nova" persona vem se impondo devido a três mudanças fundamentais, discutidas a seguir.

A primeira mudança refere-se ao fato de que algumas empresas fazem questão de se identificarem como empresa global ou como: "um importante player mundial" (VCP, Petroflex), uma empresa de "classe mundial" (Master), "uma companhia verdadeiramente global" (IBM), "uma corporação autenticamente multinacional" (Pirelli), "uma multinacional multilocal" (Unilever), uma empresa que assume definitivamente o posto de multinacional (Weg). Ainda que determinadas empresas utilizem o argumento "somos como vocês", "somos uma empresa 100\% Brasil" ou brasileira (Schinkariol, Telemar, Cimento Rio Branco), e mostrem respeito pelos costumes e tradições da cultura brasileira, a compatibilidade que se busca, prioritariamente, não é com o país no qual a empresa atua (conclusão de Halliday, 1987), mas com as outras (concorrentes). Para as empresas pesquisadas, o fato de serem globais é visto como algo positivo; é assim que elas desejam ser reconhecidas pela 
audiência. Mais importante do que se identificar com o país em que atuam, parece ser identificar-se com o que acontece "no mercado global".

A segunda mudança refere-se ao fato de que as empresas, em seu website, apresentam-se como uma empresa moderna, no sentido de ser "alguém que vive e constrói", neste momento atual, mediante o uso dos mais modernos recursos disponíveis. Caso não estejam disponíveis, a empresa poderá criá-los, visto que é flexível e bem-sucedida. A "compatibilidade" é buscada, portanto, não porque a empresa seja brasileira. A idéia presente, neste caso, é "somos como os outros", ou seja, "somos compatíveis" porque "somos tão boas quanto elas". As empresas se apresentam como alguém que é ou deseja estar entre o que há de mais moderno em termos de tecnologia, processo, estrutura e relações sociais e ferramentas de gestão. E, ser moderno, neste atual mundo dos negócios, está relacionado, também, a outro aspecto, o comportamento ético nas relações com os públicoschave e com o meio ambiente, porque essa é uma tendência em um contexto global.

A terceira mudança nesta persona está relacionada ao fato de que a consubstancialidade, ou o que liga intimamente e identifica com intimidade a empresa com o seu público, não está relacionada ao país de origem da empresa ou do público, mas aos produtos que esta empresa produz e vende e sem os quais a vida parece impossível. As empresas querem ser reconhecidas como alguém que proporciona experiências de vida. Conforme Klein (2002, p. 173), o discurso do setor de marketing tornou-se mais íntimo, "as empresas baseadas na marca não estão mais interessadas em atirar-se sobre o consumidor. Elas querem viver com ele". As empresas querem ultrapassar a necessidade de se identificarem com seus produtos terrenos e, para isso, buscam profundos significados para as suas marcas. Produtos como papel (Klabin, Aracruz, Voith), ferro (MBR), aço (CSN), petróleo (Petrobras), minério (CVRD), celulares (Nokia, Vivo), sistemas como Receitanet e Renavan (Serpro), cartões de crédito (Credicard), fazem parte do nosso dia-a-dia e, nos dias atuais, as empresas argumentam: é impossível viver sem eles (sem elas?).

Afinal, trata-se de: marcas que estão no nosso coração ou o conquistaram (Wolkswagen), empresa parte da nossa história (Wolkswagen, Grupo Pão de Açúcar, Odebrecht, Pirelli), empresa que quer fazer parte do nosso futuro (Odebrecht), uma questão de pele (sobre o jeans, Vicunha), produtos que transportam carinho e a alegria de viver (Unilever). Ou, ainda, de: empresa que busca inspiração na alma do Brasil para criar produtos com a nossa cara (Grandene), vídeos que dão um efeito especial nas melhores cenas da nossa vida (Semp Toshiba), empresa que busca contribuir para criar uma relação harmoniosa do indivíduo consigo próprio, com seu corpo, porque entende que deve, permanentemente, aprofundar seu conhecimento acerca da nossa alma (Natura). As modernas empresas dos anos 2000 estão intimamente unidas ao seu público, desde que "decidiram" que o produto se produz na fábrica, enquanto as marcas são feitas no coração, na mente e na alma das pessoas (KLEIN, 2002).

A Moderna/Irmã-em-humanidade é uma persona que busca ter sua presença compreendida e aceita como natural em nossa sociedade (taken-for-granted) e imprescindível, já que se tornou parte da nossa vida. A cognição (SUCHMAN, 1995) é o seu modus operandi de busca por legitimação. Os argumentos mobilizados por essa persona tornam impensáveis alternativas para "um mundo" sem as empresas, seus produtos e serviços, portanto, as mudanças nessa direção se tornam impossíveis. O discurso desta persona baseia-se em argumentos sutis e pode se constituir na fonte mais poderosa de legitimação para a existência da organização.

Segundo Freitas (2002, p. 97), as grandes empresas, principalmente, tendem a "homogeneizar as maneiras de pensar e agir, de criar um modo de viver específico e de captar o inconsciente dos indivíduos para incluir amor e lealdade à organização" e "induzir comportamentos indispensáveis à sua dinâmica". Assim, as organizações, com uma forma abrangente e sutil de expressão, adquirem poder à medida que se constituem em objeto de desejo, sedutor e carismático, de funcionários, clientes, acionistas, sociedades etc. O carisma institucional se desenvolve por meio da missão organizacional e de um projeto nobre, enquanto a sedução se manifesta através das tentativas de personificação e apropriação do raro pela empresa.

Entretanto, grandes empresas também se tornaram grandes alvos da militância anticorporação, especialmente, no ambiente virtual. Um discurso híbrido de "redação publicitária e Manifesto Comunista", conforme Klein (2002, p. 459), estimula uma reação ainda maior da militância. Afinal, trata-se de uma luta pelo poder, levando 
questões como padrões trabalhistas, ambientais e de comércio para além do controle corporativo, impondo-as ao domínio público. Quando a sociedade espera e procura as corporações para traçar seus códigos de direitos humanos e trabalho coletivo, está se perdendo um princípio fundamental da cidadania: as pessoas devem governar a si mesmas. Em um processo de intertextualidade, o discurso corporativo absorve as críticas sociais e os movimentos políticos como fontes de "significado" de marca, mas o que as corporações conseguem é despertar rancor ainda maior.

Em seu discurso na Web, as empresas usam de forma sistemática e entrelaçada, com diferentes intensidades, variados argumentos expressos por personas distintas, mas que trabalham juntas pela legitimação organizacional. A busca por legitimação se torna uma tarefa complexa, onerosa e com elevado grau de incerteza quanto ao seu sucesso, pois exige saber gerir "uma rede de representações" constituídas por personalidades organizacionais distintas e uma multiplicidade dinâmica de formas de legitimação: pragmatismo, cognição e moralidade. Entretanto, uma vez que a organização alcance a legitimação, ainda que nunca de forma definitiva, passa a desfrutar de maior poder para o atendimento de seus objetivos.

$\mathrm{O}$ fato de temas relevantes terem sido identificados na pesquisa da situação retórica das empresas, mas não estarem presentes nas mensagens em seus websites, pode ser atribuído ao "novo" contexto de negócios. A companhia contemporânea quer ser amada e, sobretudo, ser compreendida como bela e virtuosa. Por isso, empreende um processo complexo de construção de símbolos, legitimação de valores, idéias e sentimentos, buscando seduzir, conquistar corações e mentes de diferentes grupos de interesse. Todavia, à medida que essas informações ausentes (CHAUI, 2001) impedem a ação livre (DIJK, 2006) dos públicos-alvo da companhia, o discurso deixa de ser persuasivo e torna-se manipulativo.

\section{Conclusões}

Os textos constituem uma importante forma de ação social, uma maneira mediante a qual se exerce o controle social e a ele se resiste; disso decorre a necessidade de se ampliar os estudos sobre o discurso organizacional, situando-o histórica e socialmente. O discurso organizacional absorve e (re)elabora o material lingüístico e ideológico presente no contexto econômico, político e social, na busca por gerenciar significados e, desse modo, influenciar comportamentos, crenças, valores.

A Internet torna possível a interatividade e uma aproximação maior com o público mediante o uso de som, texto e imagem, por meio de um discurso híbrido de informação e publicidade. A estrutura da argumentação é altamente fragmentada em muitos links, possibilitando a sutileza das mensagens e inúmeros recursos para atrair o público para os temas que mais interessam à organização. Esta pesquisa usa uma metodologia pouco comum no campo dos estudos organizacionais para ampliar o conhecimento sobre a construção de sentido em um "novo" espaço: a retórica organizacional na Web.

Na pesquisa em websites de 40 empresas de 20 setores diferentes, a "melhor" e a "maior" de cada setor, verificou-se a mobilização de significados que explicam e justificam a existência da empresa, e a aceitação de seus objetivos. As companhias fazem uso de uma nova simbologia: excelência, modernidade, dinamismo, competitividade, flexibilidade, ética, responsabilidade, cidadania, comunidade/comunhão de interesses, realização de sonhos e sucesso. Esta linguagem mobiliza significado congruente com os valores, crenças e necessidades da sociedade no contexto social do início do século XXI, por exemplo, a necessidade de nos sentirmos seguros, belos, jovens e bem-sucedidos.

As empresas lêem o ambiente em que atuam e atribuem para si mesmas, no atual contexto de negócios, múltiplos papéis: são Parceiras, Modernas/Irmãs-em-humanidade e Encarregadas-de-uma-grande-missão. A legitimação é resultado de um processo complexo e altamente dinâmico que ocorre por diferentes modus operandis, tornando difícil para a audiência identificar o grau de persuasão que a empresa está utilizando. Estrategicamente, com uma argumentação caracterizada por ambigüidade, contradição e lacunas que não podem ser preenchidas, as empresas conseguem estar em todos os lugares, se propondo a atender as mais diferentes necessidades e expectativas. As falas das personae, muitas vezes, se sobrepõem nos textos virtuais. 
Os links, as cores, os sons, as imagens e o texto são articulados e assumem papel relevante na construção do sentido e na defesa de uma ideologia.

No discurso das companhias, predominam o ethos e o pathos, argumentos de natureza afetiva, em relação ao logos, argumento de ordem racional. Portanto, o discurso das empresas na Web caracteriza-se como discurso estratégico, dirigido de modo a construir sentido favorável à organização e harmonizar os resultados da empresa com os sentimentos e paixões do orador e da audiência. Esse discurso visa a reunir empresa e audiência como co-participantes de um estilo de vida e, talvez, de uma mesma visão de mundo.

A legitimação como resultado de um processo de persuasão conduzido pelo uso da linguagem é uma parte central da gestão moderna. As possibilidades para futuros trabalhos nesse campo são variadas: estudos que envolvam todos os aspectos da retórica, além da invenção, a disposição, o estilo e a ação; a intertextualidade entre o discurso organizacional e os discursos aos quais a organização responde ou antecipa; o uso de diferentes mídias no processo de busca por legitimação; análises longitudinais da busca por legitimação, considerando-se o ciclo de vida da empresa; a relação entre discurso e identidade organizacional a partir de diferentes níveis de análise; pesquisas sobre o modo de produção do conteúdo dos websites das empresas; trabalhos que apontem em que medida o conteúdo dos websites reflete o que a empresa é ou faz. E, ainda, além dessas possibilidades de pesquisa, estudos relacionados à Internet como meio e à Web como espaço ampliado para a gestão. 


\section{Referências Bibliográficas}

ALVESSON, M. Organizations: from substance to image? Organization Studies, v. 11, n. 3, p. 373-394, 1990.

ANTUNES, R. Os sentidos do trabalho. 2. ed. São Paulo: Boitempo, 2000.

ANUÁRIO "As 500 maiores empresas do Brasil: melhores e maiores". Exame, jul. 2004. EXAME. As 500 maiores empresas do Brasil: melhores e maiores. São Paulo: Ed. Abril, jul. 2004. Edição Especial.

ARISTÓTELES. Arte retórica e arte poética. Rio de Janeiro: Edições de Ouro/Tecnoprint, [19-].

ASHFORTH, B. E.; GIBBS, B. W. The double-edge of organizational legitimation. Organization Science, v. 1, n. 2, p. 177-194, 1990.

CASTELLS, M. A galáxia da Internet. Rio de Janeiro: Jorge Zahar, 2003.

CHAUI, M. Cultura e democracia. São Paulo: Cortez, 2001.

CHENEY, G. et al. Corporate Rhetoric as discourse organizational. In: GRANT, D. et al. Handbook Organizational Discourse. London/Thousand Oaks/New Delhi: Sage, 2004.

CITELLI, A. Linguagem e persuasão. São Paulo: Ática, 2004.

CLEGG, S. R. The language of power and the power of language. Organization Studies, v. 8, n. 1, p. 61-70, 1987.

COUPLAND, C.; BROWN, A. D. Constructing organizational identities on the Web: a case study of Royal Dutch/Shell. Journal of Management Studies, v. 41, n. 8, p. 1325-1346, 2004.

DIJK, T. A. V. Discourse and manipulation. Discourse \&t Society, v. 17, n.3, p. 359-383, 2006.

DIMAGGIO, P. J.; POWELL, W. W. The iron cage revisited: institutional isomorphism and collective rationality in organizational fields. American Sociological Review, v. 48, n. 2, p. 147-160, 1983.

DOWLING, J.; PFEFFER, J. Organizational legitimacy: social values and organizational behavior. Pacific Sociological Review, v. 18, n. 1, p. 122-136, 1975.

ELSBACH, K. D.; SUTTON, R. I. Acquiring organizational legitimacy through illegitimate actions: a marriage of institutional and impression management theories. Academy of Management Journal, v. 35, n. 4, p. 699-738, 1992.

FAIRCLOUGH, N. Discurso e mudança social. Brasilia: Ed. da Universidade de Brasilia, 2001.

Discourse analysis in organization studies: the case for critical realism. Organization Studies, v. 26, n. 6, p. 915-939, 2005.

FREEMAN, R. E.; REED, D. L. Stockholders and stakeholders: a new perspective on corporate governance. California Management Review, v. 25, n. 3, p. $88-106,1983$.

FREITAS, M. E. Cultura organizacional. 3. ed. Rio de Janeiro: Editora FGV, 2002.

GALLI, F. C. S. Linguagem da Internet. In: MARCUSCHI, L. A.; XAVIER, A. C. (Orgs.). Hipertexto e gêneros digitais. Rio de Janeiro: Lucerna, 2004.

GIDDENS, A. As conseqüências da modernidade. São Paulo: Unesp, 1991.

GINZEL, L. E.; KRAMER, R. M.; SUTTON, R. I. Organizational impression management as a reciprocal influence process: the neglected role of the organizational audience. In: CUMMINGS, L. L.; STAW, B. M. (Eds.). Research in Organizational Behavior, v. 15, p. 227-266. Greenwich, CT: JAI Press, 1993.

GOHN, M. G. (org.). Movimentos sociais no início do século XXI. Petrópolis, RJ: Vozes, 2003.

GRANT, D.; KEENOY, T.; OSWICK, C. Organizational Discourse: key contributions and challenges. International studies of Management \& Organization, v. 31, n. 3, p. 5-24, 2001.

GUROVITZ, H.; BLECHER, N. 0 estigma do lucro. Exame, abr., São Paulo: Ed. Abril, Edição 839, ano 39, n. 6, mar. 2005. 
HALLIDAY, T. L. A Retórica das multinacionais. São Paulo: Summus, 1987.

HARDY, C. Researching Organizational Discourse. International Studies of Management \&t Organization, v. 31, n. 3, p. 25-47, 2001.

HARVEY, D. Condição pós-moderna. 12. ed. São Paulo: Edições Loyola, 2003.

HELD, D.; McGREW, A. Prós e contras da globalização. Rio de Janeiro: Jorge Zahar Ed., 2001.

HOUTART, F.; POLET, F. (Orgs.). 0 outro Davos. São Paulo: Cortez, 2002.

HYBELS, R. C. On legitimacy, legitimation, and organizations: a critical review and integrative theoretical model. Academy of Management Journal, v. 38, p. 241-245, 1995.

KLEIN, N. Sem logo. 2. ed. Rio de Janeiro: Record, 2002.

LEACH, J. Análise retórica. In: BAUER, M. W.; GASKELL, G. (Eds.). Pesquisa qualitativa com texto, imagem e som. Petrópolis, RJ: Vozes, 2002.

LÉVY, P. Cibercultura. São Paulo: Editora 34, 1999.

LIPIETZ, A. Fordismo, fordismo periférico e metropolização. Ensaios FEE, Porto Alegre, v. 10, n. 2, p. 303-335, 1989.

LIVESEY, S. M. McDonald's and the Environmental Defense Fund: a case study of green alliance. Journal of Business Communication, v. 36, n. 1, p. 5-39, 1999.

The discourse of the middle ground: Citizen Shell Commits to sustainable development. Management Communication Quarterly, v. 15, n. 3, p. 313-349, 2002a.

Global warmingwars: rhetorical and discourse analytic approaches to ExxonMobil's corporate public discourse. Journal of Business Communication, v. 39, n. 1, p. 117-148, 2002 b.

MELO, C. T. V. A análise do discurso em contraponto à noção de acessibilidade ilimitada da Internet. In: MARCUSCHI, L. A.; XAVIER, A. C. (Orgs.). Hipertexto e gêneros digitais. Rio de Janeiro: Lucerna, 2004.

MEYER, J. W.; ROWAN, B. Institutionalized organizations: formal structure as myth and ceremony. American Journal of Sociology, v. 83, n. 2, p. 340-363, 1977.

MITCHELL, R. K.; AGLE, B. R.; WOOD, D. A. Toward a theory of stakeholder identification and salience: defining the principle of who and what really counts. Academy of Management Review, v. 22, n. 4, p. 853-886, 1997.

MOHAMED, A. A.; GARDNER, W. L.; PAOLILLO, J. G. P. A taxonomy of organizational impression management tactics. Advances in Competitiveness Research, v. 7, n. 1, p. 108-130, 1999.

PARSONS, T. Sugestões para um tratado sociológico da teoria de organização (1956). In: ETZIONI, A. Organizações complexas. São Paulo: Atlas, 1976.

PERELMAN, C.; OLBRECHTS-TYTECA, L. Tratado da argumentação. São Paulo: Martins Fontes, 1996.

PERROW, C. Organizational prestige: some functions and dysfunctions. American Journal of Sociology, v. 66, n. 4, p. 335-341, 1961.

PHILLIPS, N.; LAWRENCE, T. B.; HARDY, C. Discourse and institutions. Academy of Management Review, v. 29, n. 4, p. 635-652, 2004.

POLLACH, I. Communicating corporate ethics on the World Wide Web. Business \&t Society, v. 42, n. 2, p. 277-287, 2003.

REBOUL, O. Introdução à retórica. São Paulo: Martins Fontes, 2000.

RODRIGUES, S. B. Desafios da Administração no século XXI. Revista de Administração de Empresas - RAE. São Paulo: Fundação Getúlio Vargas, Especial Minas Gerais, v. 44, p. 108-110, 2004.

SCOT, W. R. Organizations: rational, natural, and open systems. 4th ed. New Jersey: Prentice Hall, 1998.

SILVERSTONE, R. Por que estudar a mídia? São Paulo: Loyola, 2002. 
SUCHMAN, M. C. Managing legitimacy: strategic and institutional approaches. Academy of Management Review, v. 20, n. 3, p. 571-610, 1995.

THOMPSON, J. B. Ideologia e cultura moderna. Petrópolis, RJ: Vozes, 2002.

TUCKER, L; MELEWAR, T. C. Corporate reputation and crisis management: the threat and manageability of anti-corporativism. Corporate Reputation Review, v. 7, n. 4, p. 377-387, 2005.

UNCTAD. United Nations Conference on Trade and Development. Disponível em: <http://www.unctad.org>. Acesso em: 23 jan. 2005.

WEBER, M. Economia e sociedade. Brasília: Ed. da UNB Universidade de Brasilia, 1991.

WERNERFELT, B. A resource-based view of the firm. In: FOSS, N. J. (Ed.). Resources, firms, and strategies. New York: Oxford University, 1997. 